\title{
ANALISIS MUTU SUSU TEMPE DENGAN VARIASI JENIS KACANG DAN ZAT PENSTABIL
}

\section{AN ANALYSIS OF TEMPEH MILK QUALITY WITH VARIATIONS OF BEANS AND STABILIZERS}

\author{
Herlin Santoso, Methatias Ayu Moulina \\ Fakultas Pertanian, Universitas Dehasen \\ Email : methatias_ayu_moulina@yahoo.co.id
}

\begin{abstract}
ABSTRAK
Susu tempe merupakan produk hasil ekstraksi tempe dengan air sehingga diperoleh larutan dengan komponen padatan terlarut. Masalah yang sering muncul dalam proses pembuatan susu nabati ialah rendahnya mutu susu yang dihasilkan baik dari sifat fisik, kimia maupun organoleptik. Penelitian ini ini bertujuan untuk menganalisis mutu susu tempe dengan variasi jenis kacang dan zat penstabil.

Penelitian ini menggunakan Rancangan Acak Lengkap (RAL) dengan menggunakan dua faktor beda, yaitu jenis kacang (kacang kedelai, kacang merah dan kacang hijau) serta zat penstabil (Carboxymethyl cellulose dan gum Arab konsentrasi 0,25\%) sehingga didapat 9 unit perlakuan. Masing - masing perlakuan dilakukan pengulangan sebanyak 3 kali.

Hasil analisis viskositas dan protein susu tempe menunjukkan adanya perbedaan yang nyata pada taraf signifikan 5\%. Nilai viskositas perlakuan jenis kacang ( kacang kedelai, kacang dan kacang hijau) dan penstabil (CMC dan gum arab) berkisar antara 6,30 x $10^{-3}$

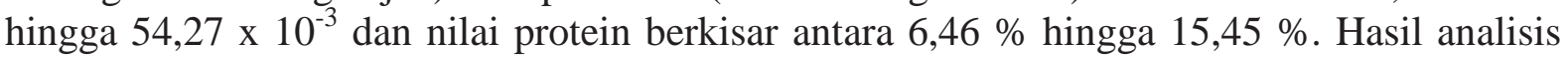
organoleptik menunjukkan bahwa perlakuan memberikan pengaruh nyata terhadap warna dan rasa pada tingkat signifikan 5\%, yaitu rata - rata penilaian terhadap warna 3,15 (agak suka) hingga 3,95 (suka) dan rasa 2,55 (agak suka) hingga 3,55 (suka) sedangkan pada variabel organoleptik terhadap aroma dan tekstur tidak berbeda nyata pada tingkat signifikan $5 \%$. Penilaian terhadap aroma 2,75 (agak suka) hingga 3,6 (suka) dan tekstur 3 (agak suka) hingga 3,6 (suka).
\end{abstract}

Kata kunci : susu tempe, jenis kacang, zat penstabil

\section{ABSTRACT}

Tempeh milk is a product of tempeh the extraction with water to obtain a solution with dissolved solids component. This study aimed to analyze the quality of tempeh milk with a variety of beans and stabilizers.

This study used completely randomized design (CRD) using two different factors, namely variety of beans (soybeans, red beans and green beans) and stabilizers (Carboxymethyl cellulose and Arabic gum concentration of $0.25 \%$ ) that gained 9 treatments unit. Each treatment be repeated 3 times.

The result of viscosity analysis and tempeh milk proteins showed significant differences at the $5 \%$ significance level. Treatment viscosity value of beans variation (soybeans, beans and green beans) and stabilizer (CMC and arabic gum) ranged between $6.30 \times 10^{-3}$ to 54.27 $x 10^{-3}$ and protein values ranged from $6.46 \%$ up to $15,45 \%$. The result of organoleptic 
analysis showed that the real effect of the color and taste to a significant level of 5\%, which the average assessment of 3.15 colors (somewhat like) to 3.95 (like) and taste of 2.55 (somewhat like) to 3.55 (like), while in the organoleptic variable of flavor and texture were not significantly different at the $5 \%$ significance level. Assessment of the flavor 2.75 (somewhat like) to 3.6 (like) and texture 3 (somewhat like) to 3.6 (like).

Keywords: tempeh milk, beans, stabilizers

\section{PENDAHULUAN}

Susu tempe merupakan produk hasil ekstraksi tempe dengan air sehingga diperoleh larutan dengan komponen padatan terlarut. Susu tempe adalah salah satu produk generasi kedua tempe (Widowati, 2005). Kelebihan susu tempe dibanding dengan susu sapi ialah susu tempe mengandung isoflavon, phytoestrogen asli, letichin, saponin dan jumlah vitamin A dan C lebih tinggi dibandingkan susu sapi serta baik dikonsumsi bagi mereka yang alergi susu sapi kemudian susu tempe memiliki sifat anti bakteri untuk mencegah penyakit diare pada anak - anak, susu tempe mengandung vit B12 yang tidak terdapat pada susu kedelai. Selain itu susu tempe tidak mengandung kolestrol, akan tetapi kandungan kalsium susu tempe lebih rendah dibandingkan susu sapi. Susu tempe lebih mahal bila dibandingkan dengan susu kedelai, karena memerlukan beberapa tahapan pengolahan, tetapi lebih unggul dari segi segi nutrisi yang dihasilkan dari proses fermentasi sebelum diolah menjadi susu (Galeaz dan Navis, 1999).
Menurut Hidayat (2008), Tempe merupakan produk fermentasi kedelai oleh jamur Rhizopus orizae. Selain jenis tempe kedelai ada jenis tempe yang lain, yakni tempe leguminosa non kedelai dan tempe non leguminosa. Tempe leguminosa non kedelai diantaranya adalah tempe benguk, tempe kecipir, tempe kedelai hitam, tempe lamtoro, tempe kacang hijau, tempe kacang merah, dan lain-lain. Sedangkan jenis tempe non leguminosa diantaranya tempe gandum, tempe sorghum, tempe campuran beras dan kedelai, tempe ampas tahu, tempe bongkrek, tempe ampas kacang, tempe tela, dan lain-lain.

Indonesia merupakan negara produsen tempe terbesar di dunia dan menjadi pasar kedelai terbesar di Asia. Sebanyak $50 \%$ dari konsumsi kedelai Indonesia dilakukan dalam bentuk tempe, $40 \%$ tahu dan $10 \%$ dalam bentuk lain (seperti tauco, kecap, dan lain-lain). Konsumsi tempe rata - rata per orang per tahun di Indonesia saat ini $6,45 \mathrm{~kg}$ (Anonim, 2012). Tempe memiliki daya simpan yang rendah dan mudah rusak. Dalam upaya meningkatkan masa simpan, 
nilai tambah, dan sifat organoleptik tempe perlu dilakukan upaya diversifikasi pengolahan tempe, salah satunya pembuatan susu tempe (Widowati, S., dkk, 2004). Selain meningkatkan umur simpan melakukan diversifikasi pengolahan juga bertujuan untuk meningkatkan konsumsi tempe.

Dalam proses pembuatan susu nabati masalah yang sering muncul ialah rendahnya mutu susu yang dihasilkan baik dari sifat fisik, kimia maupun organoleptik. Untuk itu diperlukan jenis bahan pengental yang tepat untuk meningkatkan mutu dari susu nabati. Carboxymethylcellulose (CMC) dan gum arab adalah jenis bahan tambahan makanan berupa bahan pengental yang berfungsi untuk meningkatkan viskositas dan pembentuk gel. CMC bisa ditambahkan pada proses pembuatan susu nabati (Fardiaz. dkk, 1987). Hasil penelitian terdahulu (Hapsari Titi P dan M. Saihullah), menunjukkan perlakuan terbaik yaitu kombinasi lama fermentasi 48 jam dan konsentrasi carboxymethyl cellulose (CMC) 0,25\% yaitu dengan kadar protein $1,34 \%$; total padatan terlarut 9,67 (brix), pH 6,72; organoleptik rasa 4,50 (suka); warna 4,50 (suka) ; dan aroma 4,70 (suka). Pengolahan tempe dari beberapa jenis kacang menjadi susu tempe akan meningkatkan nilai ekonomis tempe. Dengan penambahan bahan
Carboxymethyl cellulose (CMC) dan gum arab sebagai penstabil akan mempengaruhi baik atau tidaknya kualitas susu tempe yang dihasilkan. Untuk itu, perlu dikaji jenis bahan penstabil yang tepat untuk menghasilkan susu tempe kualitas baik ditinjau dari uji kimia, fisik dan organoleptik.

\section{METODE PENELITIAN}

\section{Bahan}

Bahan yang digunakan dalam penelitian ini adalah kacang kedelai, kacang merah, kacang hijau, ragi tempe, Carboxymethyl cellulose (CMC), gum Arab, air, gula.

\section{Alat}

Alat yang digunakan dalam penelitian ini adalah blender, pisau, panci kukus, baskom, sendok, kompor, saringan, kain saring, botol steril, gelas ukur, termometer, tampah, dan beberapa alat untuk uji kesukaan antara lain pulpen, borang uji organoleptik.

\section{Cara Penelitian}

\section{Pembuatan Tempe}

Adapun langkah langkah yang akan dilakukan pada tahap ini adalah :

1. Kacang kedelai sebanyak $1 \mathrm{~kg}$ yang sudah disortir dan dilakukan pencucian sampai bersih.

2. Kacang kedelai dicuci dan direbus selama 30 menit. 
3. Kacang kedelai direndam selama 24 jam dengan air rebusan, setelah itu dikupas kulit arinya.

4. Untuk kacang merah dan kacang hijau hanya dilakukan perendaman selama 12 jam, kemudian dikupas kulit arinya.

5. Kacang kedelai, kacang merah dan kacang hijau direbus selama 20 menit.

6. Kacang kedelai, kacang merah dan kacang hijau dilakukan penirisan dan pendinginan.

7. Pemberian ragi dengan perbandingan 1 gram ragi : $1 \mathrm{~kg}$ kacang.

8. Tahap akhir kacang kedelai, kacang merah dan kacang hijau dimasukkan kedalam plastik polipropylen dan plastik ditusuk tusuk dengan lidi kemudian difermentasi selama 48 jam.

\section{Pembuatan Susu Tempe}

Adapun langkah-langkah yang

dilakukan pada tahap ini adalah :

1. Tempe Kacang Kedelai, Kacang Merah dan Kacang Hijau masingmasing $1 \mathrm{~kg}$ difermentasi 48 jam.

2. Dilakukan perebusan selama 10 menit.

3. Setelah direbus, kemuadian ditiriskan dan dihaluskan dengan perbandingan tempe $:$ air $=1: 3$.

4. Dilakukan penyaringan
5. Dilakukan penambahan bahan penstabil (CMC dan Gum Arab), gula pasir 17 gram.

6. Dilakukan perebusan 30 menit 63-66 ${ }^{\circ} \mathrm{C}$.

7. kemudian dianalisis fisik (viskositas), kimia (kadar protein), dan organoleptik.

\section{Perlakuan Penelitian}

Perlakuan penelitian yang akan digunakan adalah rancangan acak lengkap (RAL) dengan menggunakan dua faktor beda, yaitu :

1. Jenis kacang $(\mathrm{K})$ :

K1 : Kacang kedelai

K2 : Kacang merah

K3 : Kacang hijau

2. Jenis bahan penstabil $(\mathrm{P})$ :

P0 : Tanpa bahan penstabil.

P1 : Carboxymethyl cellulose (CMC)

konsentrasi $0,25 \%$

P2 : Gum arab konsentrsi $(0,25 \%)$

Perlakuan :

K1P0 : Susu tempe kacang kedelai

K1P1 : Susu tempe kacang kedelai dengan konsentrasi CMC 0,25\%

K1P2 : Susu tempe kacang kedelai dengan konsentrasi gum arab $0,25 \%$

K2P0 : Susu tempe kacang merah

K2P1 : Susu tempe kacang merah dengan konsentrasi CMC 0,25\%

K2P2 : Susu tempe kacang merah dengan konsentrasi gum arab $0,25 \%$ 
K3P0 : Susu tempe kacang hijau

K3P1 : Susu tempe kacang hijau dengan konsentrasi CMC 0,25\%

K3P2 : Susu tempe kacang hijau dengan konsentrasi gum arab $0,25 \%$

\section{Analisis Penelitian}

\section{Uji Viskositas}

Viskositas dapat diukur viskosimeter dan satuan yang digunakan adalah "poise" (P). Satu poise didefinisikan tenaga dalam dyne/cm2 untuk menjaga kecepatan relatif 1 $\mathrm{cm} /$ detik antara dua bidang paralel yang bergerak terpisah $1 \mathrm{~cm}$. Viskositas susu sering dinyatakan dalam satuan "senti poice" (cP) yang nilainya sama dengan 1/100P. Viskositas susu normal besarnya adalah 1,5-2,0 cP (Sherbon, 1988).

\section{Uji Protein}

Pengukuran kadar protein paling banyak dilakukan adalah penetapan protein kasar, penetapan protein kasar bertujuan untuk menera jumlah protein total didalam bahan pangan. Metode pengukuran kadar protein tersebut ada beberapa cara antara lain : metode Kjeidhal, metode Biuret, metode Lowry dan metode pengikat zat warna (Sudarmadji et al, 1996).

\section{Uji Organoleptik}

Uji organoleptik dilakukan dengan menggunakan panelis agak terlatih sebanyak 20 orang. Uji ini menggunakan metode hedonik terhadap aspek warna, aroma, rasa dan tekstur susu tempe.

\section{Rancangan Percobaan}

Rancangan penelitian yang digunakan adalah rancangan acak lengkap (RAL) dengan menggunakan dua faktor beda jika ditemukan perbedaan yang nyata maka akan dilanjutkan dengan uji Duncan Multiple Range Test (DMRT) pada tingkat signifikan 5\% (Gomez dan Gomez, 1995).

\section{HASIL DAN PEMBAHASAN}

Viskositas Susu Tempe Variasi Jenis Kacang dan Zat Penstabil

Nilai rerata analisis terhadap viskositas susu tempe dengan perlakuan jenis kacang (kacang kedelai, kacang merah dan kacang hijau) dan zat penstabil (Carboxymethyl Nilai rerata cellulose dan gum Arab) dengan konsentrasi 0,25\% dapat dilihat pada tabel 1 .

Tabel 1 menjelaskan nilai rerata viskositas susu tempe, dimana perlakuan variasi jenis kacang (kacang kedelai, kacang merah dan kacang hijau) dan jenis zat penstabil (Carboxymethyl cellulose dan gum Arab) dengan konsentrasi 0,25\% berbeda nyata pada taraf signifikan $5 \%$. Perlakuan kacang merah dan penstabil (CMC, gum arab dan tanpa penstabil) 
menunjukkan nilai viskositas tertinggi yaitu viskositas sebesar 54,27 $\times 10^{-3}$, $36,41 \times 10^{-3}$ dan $9,51 \times 10^{-3}$ dibandingkan dengan perlakuan kacang kedelai dan penstabil (CMC, gum arab dan tanpa penstabil) yaitu viskositas sebesar $37,05 \mathrm{x}$ $10^{-3}, 6,84 \times 10^{-3}$ dan $6,30 \times 10^{-3}$ dan perlakuan kacang hijau dan penstabil (CMC, gum arab dan tanpa penstabil) yaitu viskositas sebesar $34,85 \times 10^{-3}, 6,60 \mathrm{x}$ $10^{-3}$ dan $6,33 \times 10^{-3}$. Hal ini disebabkan kacang merah yang memiliki vikositas yang besar dimana kandungan serat pangan dan pati kacang merah mempunyai peran yang cukup besar karena kedua komponen ini bersifat viskus (viskositas besar) (Marsono, 2002). Menurut Winarno (1997) pati sangat mempengaruhi viskositas karena pati dapat mengalami gelatinisasi apabila mendapatkan perlakuan panas.
Viskositas susu tempe kacang merah dan penstabil CMC menunjukkan nilai tertinggi ini disebabkan oleh ion $\mathrm{Na}^{+}$ karboksil metil selulosa (CMC) pada perlakuan. Dengan adanya ion $\mathrm{Na}^{+}$ karboksil metil selulosa (CMC) maka dapat menarik partikel - partikel endapan, sehingga dapat membentuk struktur gel. Keadaan ini didukung oleh pendapat Ganz (1997) yang menyatakan bahwa CMC memilki sifat ionik $\mathrm{Na}^{+}$karboksil metil selulosa (CMC) yang dapat menarik partikel - partikel endapan sehingga dapat membentuk struktur gel dan meningkatkan kekentalan. Penambahan CMC bertujuan untuk membentuk suatu cairan dengan kekentalan yang stabil dan homogen tetapi tidak mengendap dalam waktu yang relatif lama.

Tabel 1. Analisis Viskositas Susu Tempe Variasi Jenis Kacang dan Zat Penstabil

\begin{tabular}{|c|c|c|c|}
\hline \multirow{2}{*}{ Perlakuan } & \multicolumn{3}{|c|}{ Viskositas (poise) } \\
\hline \multirow{2}{*}{ Jenis Kacang } & \multicolumn{3}{|c|}{ Zat Penstabil } \\
\cline { 2 - 4 } & CMC & Gum Arab & Tanpa Penstabil \\
\hline Kacang Kedelai & $37,05 \times 10^{-3} \mathrm{~b}$ & $6,84 \times 10^{-3} \mathrm{~d}$ & $6,30 \times 10^{-3} \mathrm{~d}$ \\
\hline Kacang Merah & $54,27 \times 10^{-3} \mathrm{a}$ & $36,41 \times 10^{-3} \mathrm{~b}$ & $9,51 \times 10^{-3} \mathrm{c}$ \\
\hline Kacang Hijau & $34,85 \times 10^{-3} \mathrm{~b}$ & $6,60 \times 10^{-3} \mathrm{~d}$ & $6,33 \times 10^{-3} \mathrm{~d}$ \\
\hline
\end{tabular}

Ket : Angka yang diikuti oleh kode huruf yang berbeda menunjukkan adanya perbedaan yang nyata pada taraf signifikansi $5 \%$. 
CMC biasanya digunakan sebagai bahan penstabil pada produk susu seperti yogurt. Hal ini disebabkan kemampuan CMC untuk membentuk larutan kompleks dan berguna mencegah terjadinya pemisahan whey atau sineresis dan mampu meningkatkan viskositas. Menurut (Imeson, 1992), penggunaan CMC sebesar $0,3 \%$ dari volume susu akan memberikan kualitas optimum ditinjau dari $\mathrm{pH}$, keasaman, overrun dan mutu organoleptik yogurt beku. kemampuan bahan penstabil CMC membentuk sistem dispersi koloid dan meningkatkan viskositas lebih baik di bandingkan bahan penstabil gum Arab pada konsentrasi yang sama, sehingga partikel-partikel yang tersuspensi akan tertangkap dalam sistem tersebut dan tidak mengendap oleh pengaruh gaya gravitasi (Potter and Norman, 1986). CMC dapat mencegah pengendapan protein pada titik isoelektrik dan meningkatkan kekentalan, disebabkan bergabungnya gugus karboksil zat penstabil dengan gugus muatan positif dari protein (Fardiaz, 1986).

Penggunaan CMC lebih efektif dibandingkan dengan gum arab. Perlakuan kacang merah dan penstabil CMC berbeda nyata dengan perlakuan kacang merah dan penstabil gum arab dan perlakuan kacang merah tanpa penstabil. Hal ini disebabkan oleh waktu pemanasan, mengingat gum arab dapat terdegradasi secara perlahan - lahan dan kekurangan efisiensi emulsifikasi dan viskositas. Viskositas susu tempe kacang kedelai dan penstabil CMC berbeda nyata dengan perlakuan kacang kedelai dan penstabil gum arab. Perlakuan kacang hijau dan penstabil CMC juga berbeda nyata dengan perlakuan kacang hijau dan penstabil gum arab. Secara umum perlakuan bahan penstabil gum Arab pada jenis kacang kedelai dan kacang hijau tidak berbeda nyata dengan tanpa penstabil terhadap viskositas susu tempe yang dihasilkan.

\section{Kadar Protein Susu Tempe Variasi Jenis Kacang dan Zat Penstabil}

Nilai rerata analisis terhadap kadar protein susu tempe dengan perlakuan jenis kacang (kacang kedelai, kacang merah dan kacang hijau) dan zat penstabil (Carboxymethyl cellulose dan gum Arab) dengan konsentrasi $0,25 \%$ dapat dilihat pada tabel 2.

Perlakuan kacang hijau dengan penstabil (CMC, gum arab dan tanpa penstabil) menunjukkan kandungan protein lebih tinggi dibandingkan perlakuan kacang kedelai dan perlakuan kacang merah penstabil (CMC, gum arab dan tanpa penstabil), protein susu tempe kacang hijau yang tinggi ini dipengaruhi kandungan protein kacang hijau sebagai bahan baku utama yaitu $28-38 \%$. Menurut Margono (2000), kandungan 
protein kacang kedelai yaitu $25-35 \%$, kacang merah $22-28 \%$ dan kacang hijau $28-38 \%$.

Perlakuan kacang kedelai dan penstabil CMC berbeda nyata dengan perlakuan kacang hijau dan penstabil gum arab dan perlakuan kacang hijau tanpa penstabil, sedangkan perlakuan kacang merah dan kacang hijau penstabil CMC tidak berbeda nyata dengan perlakuan kacang merah dan kacang hijau dan kacang kedelai penstabil gum arab dan perlakuan kacang kedelai dan kacang merah tanpa penstabil.

Tabel 2 menjelaskan nilai rerata kadar protein susu tempe, dimana perlakuan variasi jenis kacang (kacang kedelai, kacang merah dan kacang hijau) dan jenis zat penstabil (Carboxymethyl cellulose dan gum Arab) dengan konsentrasi $0,25 \%$ berbeda nyata pada taraf signifikan 5\%. Nilai rerata kadar protein susu tempe pada perlakuan kacang kedelai, kacang merah dan kacang hijau dengan zat penstabil Carboxymethyl cellulose (CMC) konsentrasi $0,25 \%$ berkisar antara $6,46 \%$ sampai $13,59 \%$, sedangkan pada perlakuan kacang kedelai, kacang merah dan kacang hijau dengan zat penstabil gum Arab konsentrasi 0,25\% berkisar antara 8,19\% sampai 15,03\%, selanjutnya pada perlakuan kacang kedelai, kacang merah dan kacang hijau dengan tanpa zat penstabil berkisar antara $7,57 \%$ sampai $15 \%$. Kandungan protein susu tempe yang dihasilkan dalam penelitian ini sudah memenuhi standar mutu susu nabati menurut (SNI No. 013830-1995) yaitu minimal $2 \%$.

Tabel 2. Analisis Kadar Protein Susu Tempe Variasi Jenis Kacang

dan Zat Penstabil

\begin{tabular}{|c|c|c|c|}
\hline Perlakuan & \multicolumn{3}{|c|}{ Kadar Protein (\%) } \\
\hline \multirow{2}{*}{ Jenis Kacang } & \multicolumn{3}{|c|}{ Zat Penstabil } \\
\cline { 2 - 4 } & CMC & Gum Arab & Tanpa Penstabil \\
\hline Kacang Kedelai & $6,46 \mathrm{~b}$ & $8,19 \mathrm{ab}$ & $7,57 \mathrm{ab}$ \\
\hline Kacang Merah & $11,12 \mathrm{ab}$ & $9,84 \mathrm{ab}$ & $10,64 \mathrm{ab}$ \\
\hline Kacang Hijau & $13,59 \mathrm{ab}$ & $15,03 \mathrm{a}$ & $15,45 \mathrm{a}$ \\
\hline
\end{tabular}

Ket : Angka yang diikuti oleh kode huruf yang berbeda menunjukkan adanya perbedaan yang nyata pada taraf signifikansi $5 \%$. 
Uji Organoleptik Warna Susu Tempe Variasi Jenis Kacang dan Zat Penstabil

Nilai rerata analisis terhadap warna susu tempe dengan perlakuan jenis kacang (kacang kedelai, kacang merah dan kacang hijau) dan zat penstabil (Carboxymethyl cellulose dan gum Arab) dengan konsentrasi $0,25 \%$ dapat dilihat pada tabel 3 .

Susu tempe yang dihasilkan dalam penelitian ini secara keseluruhan berwarna putih kekuningan, baik perlakuan jenis kacang (kacang kedelai, kacang merah dan kacang hijau) dan bahan penstabil (CMC dan gum Arab) masing - masing konsentrasi $0,25 \%$ maupun pada perlakuan tanpa penstabil. Tabel.3 menjelaskan nilai rerata uji terhadap warna susu tempe dengan perlakuan variasi jenis kacang (kacang kedelai, kacang merah dan kacang hijau) dan zat penstabil Carboxymethyl cellulose (CMC) konsentrasi $0,25 \%$ berbeda nyata pada taraf signifikan 5\%. Nilai rerata uji organoleptik terhadap warna susu tempe pada perlakuan kacang kedelai, kacang merah dan kacang hijau dengan zat penstabil Carboxymethyl cellulose (CMC) konsentrasi $0,25 \%$ berkisar antara 4 (suka), 3,95 (suka) dan 3,2 (agak suka), sedangkan pada perlakuan kacang kedelai, kacang merah dan kacang hijau dengan zat penstabil gum Arab konsentrasi 0,25\% berkisar antara 3,15 (agak suka), 3,65 (suka) dan 3,5 (agak suka).selanjutnya pada perlakuan kacang kedelai, kacang merah dan kacang hijau dengan tanpa zat penstabil berkisar antara 3,7 (suka), 3,35 (agak suka) dan 3,3 (agak suka). Perlakuan kacang kedelai dan CMC menunjukkan warna susu tempe yang paling disukai panelis, yaitu dengan skor penilaian 4 (suka), selanjutnya perlakuan kacang merah dan CMC dengan skor penilaian 3,95 (suka).

Winarmo (1992), menyatakan bahwa uji warna lebih banyak melihat indera penglihatan dan merupakan salah satu indikator untuk menentukan apakah bahan pangan diterima atau tidak oleh konsumen, karena makanan yang berkualitas (rasanya enak, bergizi dan bertekstur baik) belum tentu disukai oleh konsumen bilamana warnanya kurang sedap dipandang atau menyimpang dari warna aslinya.

\section{Uji Organoleptik Aroma Susu Tempe} Variasi Jenis Kacang dan Zat Penstabil Nilai rerata analisis terhadap aroma susu tempe dengan perlakuan jenis kacang (kacang kedelai, kacang merah dan kacang hijau) dan zat penstabil (Carboxymethyl cellulose dan gum Arab) dengan konsentrasi $0,25 \%$ dapat dilihat pada tabel 4. 
Tabel 3. Analisis Organoleptik Warna Susu Tempe Variasi Jenis Kacang dan Zat Penstabil

\begin{tabular}{|c|c|c|c|}
\hline \multirow{2}{*}{ Perlakuan } & \multicolumn{3}{|c|}{ Warna } \\
\hline \multirow{2}{*}{ Jenis Kacang } & \multicolumn{3}{|c|}{ Zat Penstabil } \\
\cline { 2 - 4 } & CMC & Gum Arab & Tanpa Penstabil \\
\hline Kacang Kedelai & $4 \mathrm{a}$ & $3,15 \mathrm{~b}$ & $3,7 \mathrm{ab}$ \\
\hline Kacang Merah & $3,95 \mathrm{ab}$ & $3,65 \mathrm{ab}$ & $3,35 \mathrm{ab}$ \\
\hline Kacang Hijau & $3,2 \mathrm{~b}$ & $3,5 \mathrm{ab}$ & $3,3 \mathrm{~b}$ \\
\hline
\end{tabular}

Ket : Angka yang diikuti oleh kode huruf yang berbeda menunjukkan adanya perbedaan yang nyata pada taraf signifikansi $5 \%$.

Ket Skala : 1= sangat tidak suka; 2 = tidak suka; 3 =agak suka; $4=$ suka; $5=$ sangat suka

Tabel 4. Analisis Organoleptik Aroma Susu Tempe Variasi Jenis Kacang dan Zat Penstabil

\begin{tabular}{|c|c|c|c|}
\hline Perlakuan & \multicolumn{3}{|c|}{ Aroma } \\
\hline \multirow{2}{*}{ Jenis Kacang } & \multicolumn{3}{|c|}{ Zat Penstabil } \\
\cline { 2 - 4 } & CMC & Gum Arab & Tanpa Penstabil \\
\hline Kacang Kedelai & $3,55 \mathrm{a}$ & $3,3 \mathrm{ab}$ & $3,6 \mathrm{a}$ \\
\hline Kacang Merah & $3,35 \mathrm{ab}$ & $3,4 \mathrm{ab}$ & $3,35 \mathrm{ab}$ \\
\hline Kacang Hijau & $3 \mathrm{ab}$ & $2,75 \mathrm{~b}$ & $2,95 \mathrm{ab}$ \\
\hline
\end{tabular}

Ket : Angka yang diikuti oleh kode huruf yang berbeda menunjukkan adanya perbedaan yang nyata pada taraf signifikansi $5 \%$.

Ket Skala : $1=$ sangat tidak suka; $2=$ tidak suka; $3=$ agak suka; $4=$ suka; 5 = sangat suka

Susu tempe yang dihasilkan dalam penelitian ini secara keseluruhan beraroma khas tempe, karena sebelum proses pembuatan susu tempe ketiga jenis kacang (kacang kedelai, kacang merah dan kacang hijau) yang digunakan mengalami proses fermentasi terlebih dahulu selama 48 jam dengan menggunakan ragi tempe. Terbentuknya aroma dan rasa yang khas pada tempe disebabkan terjadinya degradasi komponen - komponen dalam tempe selama berlangsungnya proses fermentasi (Kasmidjo, 1990). Susu tempe perlakuan 
kacang hijau beraroma agak sidikit asam seperti aroma tape dibandingkan dengan perlakuan kacang kedelai dan kacang merah.

Tabel 4 menjelaskan nilai rerata uji terhadap aroma susu tempe dengan perlakuan variasi jenis kacang (kacang kedelai, kacang merah dan kacang hijau) dan zat penstabil Carboxymethyl cellulose (CMC) konsentrasi $0,25 \%$ tidak berbeda nyata pada taraf signifikan $5 \%$. Nilai rerata uji organoleptik terhadap aroma susu tempe pada perlakuan kacang kedelai, kacang merah dan kacang hijau dengan zat penstabil Carboxymethyl cellulose (CMC) konsentrasi 0,25\% berkisar antara 3,55 (suka), 3,35 (agak suka) dan 3 (agak suka), sedangkan pada perlakuan kacang kedelai, kacang merah dan kacang hijau dengan zat penstabil gum Arab konsentrasi $0,25 \%$ berkisar antara 3,3 (agak suka), 3,4 (agak suka) dan 2,75 (agak suka), selanjutnya pada perlakuan kacang kedelai, kacang merah dan kacang hijau dengan tanpa zat penstabil berkisar antara 3,6 (suka), 3,35 (agak suka) dan 2,95 (agak suka). Aroma susu tempe perlakuan kacang kedelai paling disukai oleh panelis yaitu dengan skor penilaian 3,6 (suka). Menurut Fennema (1996) Carboxymethylcellulose
(CMC) adalah eter asam karboksilat turunan selulosa yang berwarna putih, tidak berbau, padat serta tidak mempengaruhi aroma dan rasa apabila digunakan pada produk pangan.

\section{Uji Organoleptik Rasa Susu Tempe} Variasi Jenis Kacang dan Zat Penstabil

Nilai rerata analisis terhadap rasa susu tempe dengan perlakuan jenis kacang (kacang kedelai, kacang merah dan kacang hijau) dan zat penstabil (Carboxymethyl cellulose dan gum Arab) dengan konsentrasi $0,25 \%$ dapat dilihat pada tabel 5 .

Susu tempe yang dihasilkan dalam penelitian ini secara keseluruhan terasa manis, ini disebabkan oleh adanya penambahan gula pada proses pembuatan susu tempe yaitu dengan perbandingan 1 $\mathrm{kg}$ gula dalam 6 liter susu tempe. Susu tempe perlakuan kacang hijau memilki rasa manis agak sedikit asam dibandingkan dengan perlakuan lainnya. Menurut Fennema Carboxymethylcellulose (CMC) adalah eter asam karboksilat turunan selulosa yang berwarna putih, tidak berbau, padat serta tidak mempengaruhi aroma dan rasa apabila digunakan pada produk pangan. 
Tabel 5. Analisis Organoleptik Rasa Susu Tempe Variasi Jenis Kacang dan Zat

Penstabil

\begin{tabular}{|c|c|c|c|}
\hline \multirow{2}{*}{ Perlakuan } & \multicolumn{3}{|c|}{ Rasa } \\
\hline \multirow{2}{*}{ Jenis Kacang } & \multicolumn{3}{|c|}{ Zat Penstabil } \\
\cline { 2 - 4 } & CMC & Gum Arab & Tanpa Penstabil \\
\hline Kacang Kedelai & $3,4 \mathrm{ab}$ & $3,35 \mathrm{ab}$ & $2,85 \mathrm{ab}$ \\
\hline Kacang Merah & $2,75 \mathrm{~b}$ & $3,55 \mathrm{a}$ & $3,3 \mathrm{ab}$ \\
\hline Kacang Hijau & $2,6 \mathrm{~b}$ & $2,55 \mathrm{~b}$ & $2,65 \mathrm{~b}$ \\
\hline
\end{tabular}

Ket : Angka yang diikuti oleh kode huruf yang berbeda menunjukkan adanya perbedaan yang nyata pada taraf signifikansi $5 \%$.

Ket Skala $: 1=$ sangat tidak suka; $2=$ tidak suka; $3=$ agak suka; $4=$ suka; $5=$ sangat suka

Penilaian rasa pada produk lebih banyak melibatkan indra pengecap. Melalui lidah kita bisa merasakan rasa manis, asam, asin, pahit, gurih dan sebagainya. Rasa sangat penting dalam mempengaruhi derajat penerimaan makanan oleh konsumen (R. Choirudin,1990). Tabel .5 menjelaskan nilai rerata uji terhadap rasa susu tempe dengan perlakuan variasi jenis kacang (kacang kedelai, kacang merah dan kacang hijau) dan zat penstabil Carboxymethyl cellulose (CMC) konsentrasi $0,25 \%$ berbeda nyata pada taraf signifikan 5\%. Nilai rerata uji organoleptik terhadap rasa susu tempe pada perlakuan kacang kedelai, kacang merah dan kacang hijau dengan zat penstabil Carboxymethyl cellulose (CMC) konsentrasi $0,25 \%$ berkisar antara 3,4 (agak suka), 2,75 (agak suka) dan 2,6 (agak suka), sedangkan pada perlakuan kacang kedelai, kacang merah dan kacang hijau dengan zat penstabil gum Arab konsentrasi $0,25 \%$ berkisar antara 3,35 (agak suka), 3,55 (suka) dan 2,55 (agak suka), selanjutnya pada perlakuan kacang kedelai, kacang merah dan kacang hijau dengan tanpa zat penstabil berkisar antara 2,85 (agak suka), 3,3 (agak suka) dan 2,65 (agak suka). Susu tempe perlakuan kacang merah paling disukai oleh panelis yaitu dengan skor penilaian 3,55 (suka).

Susu tempe yang dihasilkan dari perlakuan jenis kacang (kacang kedelai, kacang merah dan kacang hijau) dan zat penstabil (CMC dan gum Arab) dalam penelitian ini menunjukkan tidak ada pengaruh antara tinggi rendahnya kandungan protein susu tempe terhadap 
tingkat kesukaan rasa oleh panelis. Kandungan protein susu tempe tertinggi pada perlakuan kacang hijau tanpa penstabil yaitu $15,45 \%$ sedangkan tingkat kesukaan rasa yang paling disukai yaitu pada susu tempe perlakuan kacang merah dan gum Arab.

\section{Uji Organoleptik Tekstur Susu Tempe} Variasi Jenis Kacang dan Zat Penstabil

Nilai rerata analisa terhadap tekstur susu tempe dengan perlakuan jenis kacang (kacang kedelai, kacang merah dan kacang hijau) dan zat penstabil (Carboxymethyl cellulose dan gum Arab) dengan konsentrasi $0,25 \%$ dapat dilihat pada tabel 6 .

Tabel 6 menjelaskan nilai rerata uji terhadap tekstur susu tempe dengan perlakuan variasi jenis kacang (kacang kedelai, kacang merah dan kacang hijau) dan zat penstabil Carboxymethyl cellulose (CMC) konsentrasi $0,25 \%$ tidak berbeda nyata pada taraf signifikan 5\%. Nilai rerata uji organoleptik terhadap tekstur susu tempe pada perlakuan kacang kedelai, kacang merah dan kacang hijau dengan zat penstabil Carboxymethyl cellulose (CMC) konsentrasi 0,25\% berkisar antara 3,6 (suka), 3,45 (agak suka) dan 3,05 (agak suka), sedangkan pada perlakuan kacang kedelai, kacang merah dan kacang hijau dengan zat penstabil gum Arab konsentrasi $0,25 \%$ berkisar antara 3,2 (agak suka), 3,2 (agak suka) dan 3,3 (agak suka), selanjutnya pada perlakuan kacang kedelai, kacang merah dan kacang hijau dengan tanpa zat penstabil berkisar antara 3,35 (agak suka), 3 (agak suka) dan 3,05 (agak suka).

Tabel 6. Analisa Organoleptik Tekstur Susu Tempe Variasi Jenis Kacang dan Zat Penstabil

\begin{tabular}{|c|c|c|c|}
\hline Perlakuan & \multicolumn{3}{|c|}{ Tekstur } \\
\hline \multirow{2}{*}{ Jenis Kacang } & \multicolumn{3}{|c|}{ Zat Penstabil } \\
\cline { 2 - 4 } & CMC & Gum Arab & Tanpa Penstabil \\
\hline Kacang Kedelai & $3,6 \mathrm{a}$ & $3,2 \mathrm{a}$ & $3,35 \mathrm{a}$ \\
\hline Kacang Merah & $3,45 \mathrm{a}$ & $3,2 \mathrm{a}$ & $3 \mathrm{a}$ \\
\hline Kacang Hijau & $3,05 \mathrm{a}$ & $3,3 \mathrm{a}$ & $3,05 \mathrm{a}$ \\
\hline
\end{tabular}

Ket : Angka yang diikuti oleh kode huruf yang berbeda menunjukkan adanya perbedaan yang nyata pada taraf signifikansi $5 \%$.

Ket Skala $: 1=$ sangat tidak suka; $2=$ tidak suka; $3=$ agak suka; $4=$ suka; $5=$ sangat suka 
Tingkat kesukaan panelis terhadap tekstur susu tempe perlakuan jenis kacang (kacang kedelai, kacang merah dan kacang hijau) dan zat penstabil (CMC dan gum Arab) tidak menunjukkan perbedaan yang nyata karena rata - rata panelis memiliki tingkat kesukaan yang sama, ini dapat dilihat dari hasil rerata analisa organoleptik tekstur yaitu berkisar antara 3,05 (agak suka) hingga 3,6 (suka).

\section{KESIMPULAN}

1. Hasil analisa terhadap viskositas susu tempe berkisar antara $6,30 \times 10^{-3}$ hingga $54,27 \times 10^{-3}$. Perlakuan jenis kacang (kacang kedelai, kacang merah dan kacang hijau) dan zat penstabil (CMC) memberikan pengaruh yang nyata terhadap viskositas susu tempe, perlakuan kacang merah dan penstabil CMC menghasilkan viskositas tertinggi yaitu $54,27 \times 10^{-3}$ sedangkan perlakuan kacang kedelai tanpa penstabil menghasilkan viskositas terendah yaitu $6,30 \times 10^{-3}$. Perlakuan kacang kedelai dan kacang hijau pada penstabil gum Arab menunjukkan tidak berbeda nyata.

2. Hasil analisa kadar protein susu tempe berkisar antara 6,46\% hingga $15,45 \%$. Perlakuan jenis kacang (kacang kedelai, kacang merah dan kacang hijau) memberikan pengaruh nyata terhadap kadar protein susu tempe, sedangkan perlakuan jenis zat penstabil tidak berpengaruh terhadap kadar protein susu tempe.

3. Hasil analisa uji sensoris terhadap warna dan rasa menunjukkan berbeda nyata pada taraf signifikan 5\%. Dimana perlakuan jenis kacang (kacang kedelai, kacang merah dan kacang hijau) dan zat penstabil CMC dan gum Arab memberikan pengaruh warna dengan penilaian 3,15 (agak suka) hingga 4 (suka), rasa berkisar 2,55 (agak suka) hingga 3,55 (suka), sedangkan perlakuan jenis kacang dan zat pentabil menunjukkan tidak berbeda nyata terhadap aroma yaitu dengan penilaian 2,75 (agak suka) hingga 3,6 (suka) dan tekstur dengan penilaian berkisar 3 (agak suka) hingga 3,6 (suka).

\section{DAFTAR PUSTAKA}

Anonim. 2012. Tempeh info.www.tempeinfo.com

Fardiaz, S. 1986. Mikrobiologi Pangan. PT.Gramedia Pustaka. Jakarta

Fardiaz, Srikandi, Ratih Dewanti, Slamet Budijanto. 1987. Risalah Seminar ; Bahan Tambahan Kimiawi (FoodAdditive). Institut Pertanian Bogor, Bogor.

Febryanto, E. 2008. Colloides naturels international memperkenalkan keunggulan dan nilai lebih gum acacia. Food Review Indonesia.111 (6): 44-47

Fennema, Owen. 1996. Food Chemistry. Third Edition. Chemical 
Publishing Company Inc. New York.

Galeaz, R.D. and Navis, S.R., 1999, Soymilk- DrinkUp, Soyfoods USA, Vol. 4 (8), http://www.soyfoods.com/newlett er/ [30 April 2010].

Gomez, K. A., dan Gomez, A.A., 2005. Prosedur Statistik Untuk Penelitian Pertanian, edisi kedua, UI Press, Jakarta.

Hidayat N.,dkk. 2006. Mikrobiologi Industri.Yogyakarta,Andi. 2008. Fermentasi

Tempe.http://ptp2007.files.wordp ress.com/2008/03/fermentasitempe.pdf. Diakses pada tanggal 02 Februari 2012, Makassar.

Imeson, A.1992. Thickening and Gelling Agents for Food. Blackie Academic \& Professional. New York

Kasmidjo, R.B. 1990. Tempe : Mikrobiologi dan Biokimia Pengolahan serta Pemanfaatannya. PAU Pangan dan Gizi. UGM, Yogyakarta.

Potter W. and Norman, N. 1986. Food Science. The AVI Publishing Co, Inc. Westport. Connecticut
SNI.01-3144-1992. Syarat Mutu Tempe Kedelai. Badan Standarisasi Nasional Indonesia : Jakarta.

SNI.01-3951-1995. Susu Pasteurisasi. Badan Standarisasi Nasional Indonesia : Jakarta.

SNI.01-3141-1998. Syarat Mutu Susu Segar. Badan Standarisasi Nasional Indonesia : Jakarta.

SNI.01-3830-2006. Syarat Mutu Susu Kedelai. Badan Standarisasi Nasional Indonesia : Jakarta.

SNI.01-3144-2009. Syarat Mutu Tempe. Badan Standarisasi Nasional Indonesia : Jakarta.

Sudarmadji et al (1996). Analisa Bahan Makanan dan Pertanian. Liberty dan PAU pangan dan Gizi UGM, Yogyakarta.

Widowati, S . 2004. Tempe dan Produk Turunannya : Pangan Fungsional Indigenous Indonesia. Dalam Prosiding Seminar Nasional Peningkatan Daya Saing Pangan Tradisional. Balai Besar Penelitian Dan Pengembangan Pascapanen Pertanian. Hal 220 228.

Winarno, F., G., 1993, Pangan, Gizi, Teknologi dan Konsumen. PT. Gramedia Pustaka Utama, Jakarta. 